Arab Univ. J. Agric. Sci., Ain Shams Univ., Cairo, 13(3), 669 - 676, 2005

\title{
ANTIBACTERIAL ACTIVITY OF GARLIC EXTRACT AND DEHYDRATED GARLIC POWDER AGAINST LISTERIA monocytogenes IN SYNTHETIC MEDIUM AND SOFT CHEESE
}

\author{
Al-Hindi' ${ }^{1}$ R.R. and S. Abd El-Ghani ${ }^{2}$
}

\begin{abstract}
The antibacterial effect and minimal inhibitory concentration (MIC) of garlic extract and MIC of dehydrated garlic powder (DGP) against Listeria monocytogenes were studied. Its use as an additional barrier in the hurdle technology concept against cross contamination by such pathogen during soft cheese processing was investigated. The agar well diffusion method (Benkerroum and Sandine 1998) and the method of Hogg et al (1987) were used to determine the antilisterial activity and minimal inhibitory concentration (MIC) of garlic extract and its powder respectively. Garlic extract showed antilisterial effect on plates of tryptose soy agar as revealed by inhibition zones ranged from 10 to $19 \mathrm{~mm}$ diameter, depending on the strain used. MIC for garlic extract was $2 \%$ while it was $3 \%$ for $\mathrm{DGP}_{1}, \mathrm{DGP}_{2}, \mathrm{DGP}_{4}$, $\mathrm{DGP}_{5}$ and $>5 \%$ for $\mathrm{DGP}_{3}$. The potency of garlic powder against the pathogen depends on the temperature used in its processing. Addition of $3 \%$ garlic extract to milk intended for soft cheese processing artificially contaminated with $10^{4} \mathrm{cfu} / \mathrm{ml}$ of the pathogen resulted in producing safe soft cheese. The pathogen could not be detected in soft cheese after $24 \mathrm{~h}$ from its addition to cheese milk.
\end{abstract}

Key words: Listeria monocytogenes, Garlic, Soft cheese

\section{INTRODUCTION}

Listeria monocytogenes is a Gram positive nonsporing rods pathogenic bacteria which causes listeriosis in human subjects. Since 1980 s a number of major outbreaks of human listeriosis were shown to be food- related (Harvey and Gilmour 1992), of which dariy products shared high degree of probability such as Mexican style soft cheese (James et al 1985) and Swiss regional- type soft

1- Department of Biological Sciences, Faculty of Science, King Abdulaziz University, P.O. Box 80203, Jeddah 21589, Saudi Arabia

2- Department of Dairy Science, Food Science and Nutrition Division, National Research Centre, Dokki, 12311, Giza, Egypt

(Received June 13, 2005)

(Accepted June 18, 2005) 
Arab Univ. J. Agric. Sci., Ain Shams Univ., Cairo, 13(3), 669 - 676, 2005

cheese (Bille and Glauser 1988). Also

sporadic listeriosis was attributed to consumption of soft cheese in England (Brannister, 1987) and camembert cheese in Belgium (Gilot et al 1997). Soft cheese are particularly sensitive to colonization with L.monocytogenes

\section{(Ennahar et al 1994 and 1998).}

In general, soft cheese owes its safety against pathogenic bacteria to particular environmental barriers such as low $\mathrm{pH}$, salt content and cold storge of the product (Farber and Petrkin 1991). However, these barriers may be challenged by the ability of L.monocytogenes to grow and proliferate under these conditions (Gay and Cerf 1997 and Wang and Johnson 1997). Therefore, additional barriers against L.monocytogenes in soft cheese are of great interest and seem to be indispensable.

The antimicrobial activity of several plants and their essential oils on some food borne and food spoilage microorganisms have been studied (EIGayyar et al 2001). In this concern, the antimicrobial properties of Allium sativum (garlic) was documented over the decades (Harris et al 2001). Garlic has been used worldwide as a spice, food and folk medicine (Naganawa et al 1996).

Recent public health concern about L.monocytogenes in soft cheese created a dilemma to dairy industry and the problem ought to be controlled. Therefore, this study was planned first to determine the antilsterial activity of aqueous garlic extract against 10 strains of L. monocytogenes. Second, the minimal inhibitory concentration (MIC) for aqueous garlic extract and five dehydrated garlic powder were defined. Lastly, the survival of L. monocytogenes artificially inoculated into cheese milk intended for processing was monitored in the cheese stored at $8-10^{\circ} \mathrm{C}$ for 12,24 and $48 \mathrm{~h}$.

\section{MATERIAL AND METHODS}

Cultures: Ten strains of $L$. monocytogenes were graciously provided by Prof. Tham of the Swedish University of Agricultural Sciences, Uppsals, Sweden. Table (1) shows their identities. Stock cultures were kept in a deep freezer $\left(-20^{\circ} \mathrm{c}\right)$. Working strains were transferred to $10 \mathrm{ml}$ tubes of tryptose soy broth (Oxoid) supplemented wit $0.6 \%$ yeast extract and incubated at $37^{\circ} \mathrm{c}$ for $16 \mathrm{~h}$.

\section{1- Garlic preparations}

\section{1- Dehydrated garlic powder}

Five preparations of dehydrated garlic powder (DG) designated Dg1, 2, 3, 4 and 5 were obtained from prof. S. Imbaby, Department of Pharmaceutical research, National Research Center, Egypt.

Samples were stored in tightly sealed containers at room temperature $\left(30^{\circ} \mathrm{c}\right)$ until used. Stock solutions were prepared by adding sterilized water to equal amounts of the powder $(1: 1 \mathrm{w} / \mathrm{w})$ and the

1- Department of Biological Sciences, Faculty of Science, King Abdulaziz University, P.O. Box 80203, Jeddah 21589, Saudi Arabia

2- Department of Dairy Science, Food Science and Nutrition Division, National Research Centre, Dokki, 12311, Giza, Egypt

(Received June 13, 2005)

(Accepted June 18, 2005) 
671

$$
\text { Antibacterial activity of garlic in soft cheese }
$$

reconstituted solution was used in the study.

\section{2- Garlic extract preparation}

Fresh garlic bulbs were obtained from the local market. The extract was prepared by the procedure of Saleem and Al-Delaimy (1982). The extract was used

3- Determination of antilisterial activity of aqueous garlic extract

The method described by Benkerrum and Sandine (1998) was used. The inhibition zone diameters were measured as $\mathrm{mm}$. within $3 \mathrm{~h}$ of preparation. 
Arab Univ. J. Agric. Sci., Ain Shams Univ., Cairo, 13(3), 669 - 676, 2005

Table 1. Identity of 10 strains of L. monocytogenes used

\begin{tabular}{|cccc|}
\hline Code No. & Serovar & Origin & Year of isolation \\
\hline 770 & $1 / 2 \mathrm{a}$ & Cheese & 1987 \\
773 & $1 / 2 \mathrm{~b}$ & Cheese & 1987 \\
1116 & $1 / 2 \mathrm{c}$ & Human & 1985 \\
1514 & $3 \mathrm{~b}$ & Salmon & 1993 \\
1877 & $4 \mathrm{~b}$ & Salmon & 1993 \\
1951 & $1 / 2 \mathrm{~b}$ & Salmon & 1993 \\
2112 & $3 \mathrm{~b}$ & Cheese & 1994 \\
2128 & $1 / 2 \mathrm{a}$ & Human & 1988 \\
2315 & 46 & Coleslaw & 1981 \\
2317 & 46 & Human & 1989 \\
\hline
\end{tabular}

\section{4- Determination of minimal inhibitory concentration (MIC)}

The MIC determination for aqueous garlic extract and five dehydrated garlics were done according to the method of Hogg et al (1987). Plates of tryptose soy agar (TSA) containing $0,1,2,3$ and 4 percent aqueous garlic or $0,1,3$ and 5 percent reconstituted garlic (prepared from dehydrated garlic) were seeded with a drop from active culture of $L$.

monocytogenes and incubated at $37^{\circ} \mathrm{C}$ for $24 \mathrm{~h}$. The concentration of garlic was considered antilisterial when no growth could be observed after $48 \mathrm{~h}$ incubation.

\section{5- Experimental soft cheese with garlic}

Soft cheese was manufactured using 251 pasteurized cow's milk $\left(63^{\circ} \mathrm{c} / 30 \mathrm{~min}\right)$ of $3 \%$ fat. Cheese milk was tempered to $50^{\circ} \mathrm{C}$ and 5 percent sodium chloride was added. Prepared milk was distributed into 5 beakers each containing 51 resembling five treatments $\left(T_{1}\right.$ to $\left.T_{5}\right) . T_{1}$ with no garlic, $T_{2}, T_{3}$ and $T_{4}$ with 1,2 and 3 percent added garlic extract respectively. The remaining $\mathrm{T}_{5}$ was supplemented with 3 percent garlic extract to process soft cheese for sensory evaluation therefore

1- Department of Biological Sciences, Faculty of Science, King Abdulaziz University, P.O. Box 80203, Jeddah 21589, Saudi Arabia

2- Department of Dairy Science, Food Science and Nutrition Division, National Research Centre, Dokki, 12311, Giza, Egypt 
Arab Univ. J. Agric. Sci., Ain Shams Univ., Cairo, 13(3), 669 - 676, 2005

no pathogen was added. The four aforementioned treatments $T_{1}$ to $T_{4}$ were first inoculated with $1 \mathrm{ml}$ of active $L$. monocytogenes (about $10^{4} \mathrm{cfu} / \mathrm{ml}$ ) then rennet was added and the procedure was continued to obtain soft cheese.

Experimental cheeses were kept in plastic containers at $8-10^{\circ} \mathrm{c}$ and examined after 12,24 and $48 \mathrm{~h}$ from adding garlic to cheese milk. Listeria selective agar (Oxford formulation, (Oxoid) was used for monitoring the pathogen in cheese sample examined.

\section{6- Sensory evaluation of garlic soft cheese}

Soft cheese made from $\mathrm{T}_{5}$ was subjected for sensory evaluation by staff members of the Dairy Department, NRC.

\section{RESULTS AND DISCUSSION}

\section{1- Antilisterial activity of garlic extract}

All tested strains of L.monocytogenes were inhibited by garlic extract as shown in Table (2) with different degrees. In this regard, the most sensitive strain towards the effect of garlic was the one No. 773 . Contrary, strain No. 2315 proved to be the most resistant strain tested. Human listeriosis may be caused by many serovars of L.monocytogenes including serovars $1 / 2 \mathrm{a}, 1 / 2 \mathrm{~b}$ and $4 \mathrm{~b}$ which were frequently incriminated in most cases (Farber and Peterkin 1991). All these serovars were sensitive to the antibacterial activity of garlic. It could be concluded that the sensitivity of $L$. monocytogenes to garlic is strain dependent which coincided with other workers (Hefnawy et al 1993).

\section{2- Determination of minimum inhibitory concentration (MIC)}

The MIC as percent garlic extract or dehydrated garlic powder (v/v) were shown in Table (3). Two percent garlic extract inhibited all the tested strains of $L$. monocytogenes on TSA at $\mathrm{pH}$ 7.3. Lower concentrations of one percent garlic extract was not enough to inhibit all the tested strains. For the different five garlic powder preparations examined, it could be observed that $\mathrm{Dg}_{4}$ was the most inhibitory while $\mathrm{Dg}_{3}$ was the least active preparation and $\mathrm{Dg}_{1}, \mathrm{Dg}_{2}$ and $\mathrm{Dg}_{5}$ were equally similar. The potency of a given dehydrated garlic as revealed from this study against the pathogen may be attributed to the method used in its preparation and drying. Heat applied in drying of garlic cloves may causes an adverse effect to the naturally occurring antimicrobials as elucidated by Lawson and Hughes (1992).

Table 2. Diameter of inhibition zones (mm) of L. monocytogenes (10 strains) caused by garlic aqueous extract using well diffusion method

Diameter of

1- Department of Biological Sciences, Faculty of Science, King Abdulaziz University, P.O. Box 80203, Jeddah 21589, Saudi Arabia

2- Department of Dairy Science, Food Science and Nutrition Division, National Research Centre, Dokki, 12311, Giza, Egypt

(Received June 13, 2005)

(Accepted June 18, 2005) 


\begin{tabular}{|ccc|}
1116 & $1 / 2 c$ & 16 \\
1514 & $3 b$ & 16 \\
1877 & $4 b$ & 12 \\
1951 & $1 / 2 b$ & 14 \\
2112 & $3 b$ & 16 \\
2128 & $1 / 2 a$ & 16 \\
2315 & $4 b$ & 10 \\
2317 & $4 b$ & 11 \\
\hline
\end{tabular}

3- Viability loss of $L$. monocytogenes by garlic homogenate in soft cheese

Control soft cheese $\left(\mathrm{T}_{1}\right)$ (No added garlic) made from inoculated milk with $10^{4} \mathrm{cfu} / \mathrm{g}$ of L. monocytogenes developed enormous growth after 24 and $48 \mathrm{~h}$ being $2 \times 10^{7}$ and $5 \times 10^{9} \mathrm{cfu} / \mathrm{g}$ respectively (Table 4). Garlic soft cheeses prepared using 1,2 and $3 \%$ garlic extract $\left(\mathrm{T}_{2}, \mathrm{~T}_{3}\right.$ and $\mathrm{T}_{4}$ respectively) showed different behaviour. 
Arab Univ. J. Agric. Sci., Ain Shams Univ., Cairo, 13(3), 669 - 676, 2005

1- Department of Biological Sciences, Faculty of Science, King Abdulaziz University, P.O. Box 80203, Jeddah 21589, Saudi Arabia

2- Department of Dairy Science, Food Science and Nutrition Division, National Research Centre, Dokki, 12311, Giza, Egypt

(Received June 13, 2005)

(Accepted June 18, 2005) 
Increasing the percentage of the spice was accompanied with decrease in counts of the pathogen (see Table 4).

Table 4. Survival of $L$.monocytogenes as $\mathrm{cfu} / \mathrm{g}$ in soft cheese

\begin{tabular}{|lcc|}
\hline \multirow{2}{*}{ Treatment } & \multicolumn{2}{c|}{ Count cfu/g } \\
& \multicolumn{2}{c|}{ L. monocytogenes } \\
\cline { 2 - 3 } & $24 \mathrm{~h}$ & $48 \mathrm{~h}$ \\
\hline Control & $1 \times 10^{7}$ & $5 \times 10^{9}$ \\
$\left(\mathrm{~T}_{1}\right.$ No garlic) & & \\
$\mathrm{T}_{2}(1 \%)$ & $5 \times 10^{3}$ & $4 \times 10^{2}$ \\
$\mathrm{~T}_{3}(2 \%)$ & $2 \times 10$ & $<10$ \\
$\mathrm{~T}_{4}(3 \%)$ & $<10$ & $<10$ \\
\hline
\end{tabular}

The behaviour of the spice in the food matrix may differ from synthetic medium as observed in the present study and reported by other investigator (Aureli et al 1992 and Hao et al 1998).

From the results obtained, it was necessary to add an additional barrier(s) to soft cheese. The garlic is a natural product generally used worldwide with no known adverse effect. Inclusion of garlic in the diet should be considered mandatory to maintain good health (Thomson and Ali 2003).

The sensory characteristics of garlic soft cheese were shown by Table (5). The most accepted treatment was that manufactured with $3 \%$ garlic homogenate. Not only garlic extract inhibited the growth of $L$. monocytogenes in soft cheese but also it enhanced the growth of lactic acid bacteria normally found in the raw milk in case soft cheese will be processed from unpasteruzied milk (data not shown).
In conclusion, garlic extract at 3\% $(\mathrm{v} / \mathrm{v})$ of cheese milk could be used to control the problem of L.monocytogenes in soft cheese whether the pathogen contaminates the product during manufacture or subsequently after opening the packages and kept for consumption.

Table 5. Sensory evaluation of garlic soft cheese with 1,2 and 3 percentage $(\mathrm{v} / \mathrm{v})$ garlic extract

\begin{tabular}{|lllll|}
\hline \multicolumn{1}{c}{ Item } & Scores & $\mathrm{T}_{2}$ & $\mathrm{~T}_{3}$ & $\mathrm{~T}_{4}$ \\
\hline Colour & 5 & 4 & 4 & 5 \\
Texture & 40 & 30 & 30 & 38 \\
Flavour & 40 & 20 & 35 & 40 \\
Appearance & 10 & 5 & 7 & 9 \\
Taste & 5 & 2 & 2 & 4 \\
\cline { 2 - 6 } & 100 & 61 & 78 & 96 \\
\hline
\end{tabular}

\section{REFERENCES}

\author{
Aureli, P.; A. Costantini and S. Zolea \\ (1992). Antimicrobial activity of some \\ plant essential oils against $L$. \\ monocytogenes J. Fd. Prot., 55: 344-348.
} Benkerroum, N. and W.E. Sandine (1998). Inhibitory action of nisin against L. monocytogenes. J. Dairy Sci. 71: 3237-3245.

Bille, J. and M.P. Glauser (1988). Listeriose en Swisse. Bull. de L'office de La Sante Publique, Swiss, 3: 28-29. Brannister, B. (1987). L.monocytogenes meningitis associated with eating soft cheese. J. Infection 15: 165-168. ElGayyar, M.; F.A. Draughon; D.A. Golden and J.R. Mount (2001). Antimicrobial Activity of essential oils 
from plants against selected pathogenic and saprophytic microorganisms. $\boldsymbol{J} . \boldsymbol{F d}$. Prot., 64: 1019-1024.

Ennahar, S.; F. Kutz; A. Strasser; M. Bergventzle; C. Hasselmann and V. Stahl (1994). Elimination of $L$. monocytogenes in soft and red smear cheeses by irradiation with low energy electrons. Int. J. Fd. Sci. \& Technol. 29: 395-403.

Ennahar, S.; O. Assobhei and C. Hasselmann (1998). Inhibition of $L$. monocytogenes is a smear surface soft cheese by L. plantarum WHE92, a pediocin ACH producer. J. Fd. Prot. 61: 186-191.

Farber, J. and P. Peterkin (1991). Listeria monocytogenes a food-borne pathogen. Microbial. Rev. 55: 476-511. Gay, M. and O. Cerf (1997).

Significance of temperature and pre incubation temperature on survival of $L$. monocytogenes at $\mathrm{pH}$ 4.80. Lett Appl. Microbiol. 25: 257-260.

Gilot, P.; C. Hemans; M. Yde; J. Gigi; M. Janssens; A. Genicot; P. Andre and G. Wanters (1997). Sporadic case of listeriosis associated with the consumption of a L.monocytogenes contaminated camembert cheese. $\boldsymbol{J}$. Infect. 35: 195-197.

Hao, Y.; R. Brackett and M. Doyle (1998). Inhibition of L.monocytogenes and A. hydrophile by plant extract in refrigerated cooked beef. J. Fd. Prot. 61: 307-312.

Harris, J.; S. Cotrell, S. Plummer and D. Lloyd (2001). Antimicrobial properties of Allium Sativum (garlic). Appl. Microbiol. Biotechnol. 57: 282286.

Harvey, J. and A. Gilmour (1992). Occurrence of Listeria species in raw milk and dairy products produced in northern Irland. J. Appl. Bact. 72: 119-125.

Hefnawy, Y.; S. Moustafa and E. Marth (1993). Sensitivity of $L$. monocytogenes to selected spices. $\mathbf{J} . \mathbf{F d}$. Prot. 56: 876-878.

Hogg, G.; M. Patterson and J. Barr (1987). Correlation between antibiotic sensitivity testing by conventional and conductivity measurements. J. Appl. Bact. 62: 189-192.

James, S.; S. Fannin; B. Agee; B. Hall; E. Parder; J. Vogt; G. Run; J. Williams; L. Lieb; T. Prendergast; S. Werber and J. Chin (1985). Listeriosis outbreak associated with Mexican style cheese. California Morbid. Mortal. Wkly. Rep. 34: 357-359.

Lawson, L. and B. Hughes (1992). Characterization of the formation of allicin and other thiosulfinates from garlic. Planta Med. 58: 345-350. Naganawa, R.; N. Iwata; K. Ishikawa; H. Fukuda; T. Fujino and A. Suzuki (1996). Inhibition of microbial growth by Ajoene, a sulfur containing compound derived from garlic. Appl. And Enivorn. Microbiol. 62: 2438-4242.

Saleem, Z. and K. Al-Delaimy (1982). Inhibition of $B$. cereus by garlic extract. J. Fd. Prot. 45: 1007-1009.

Thomson, M. and M. Ali (2003). Garlic (Allium sativum): A review of its potential use as an anti-cancer agent. Current. Cancer Drug Targets, 3: 67-81. Wang, L. and E. Johnson (1997). Control of L.monocytogenes by monoglycerides in foods. J. Fd. Prot., 60: 131-138. 
Arab Univ. J. Agric. Sci., Ain Shams Univ., Cairo, 13(3), 669 - 676, 2005

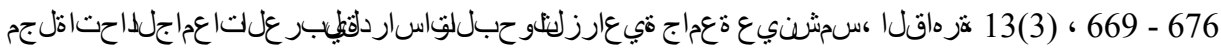
، 2005

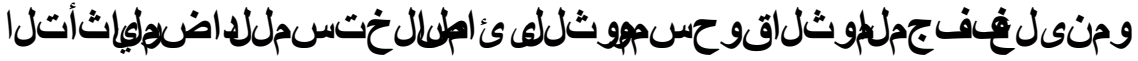

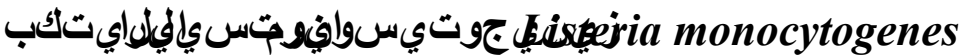

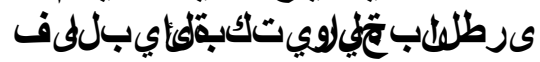

\section{]43[}

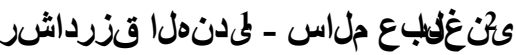

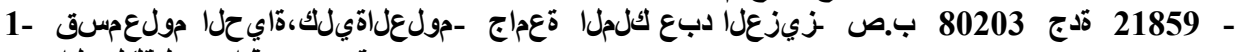

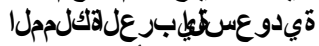

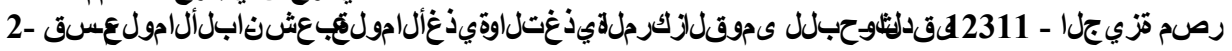

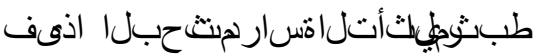

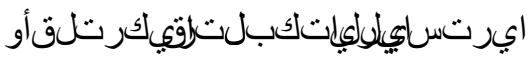

دن ع نياجوت تيسونوم

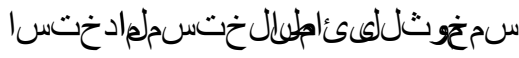

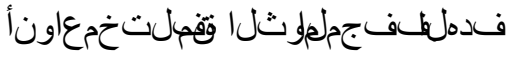

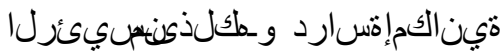

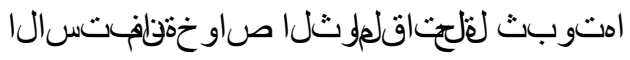

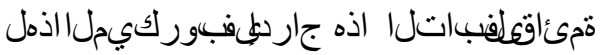

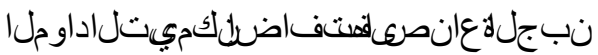

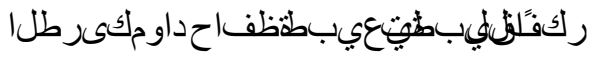

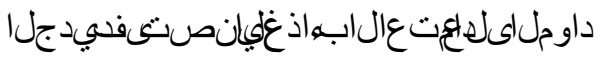

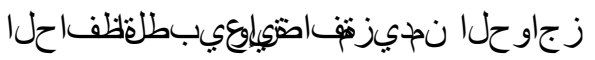

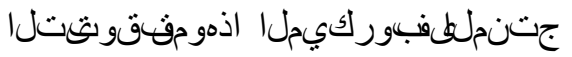

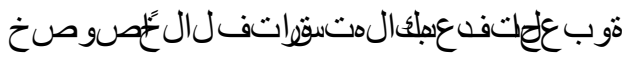

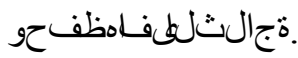

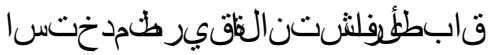

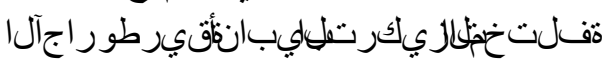

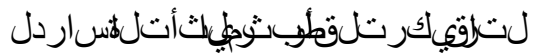

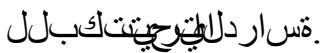

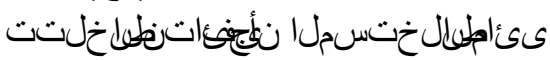

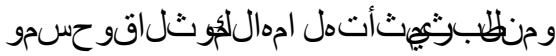

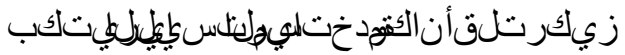

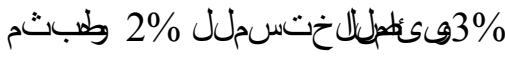
فف جملعلثل

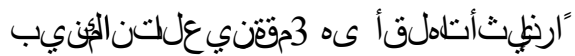

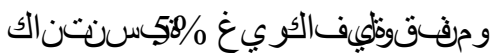

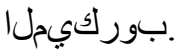

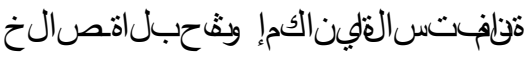

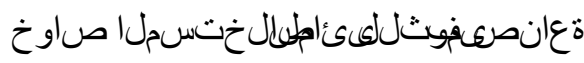

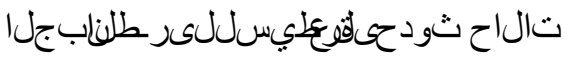

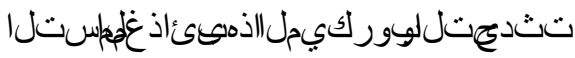

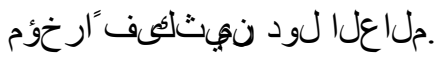

1- Department of Biological Sciences, Faculty of Science, King Abdulaziz University, P.O. Box 80203, Jeddah 21589, Saudi Arabia

2- Department of Dairy Science, Food Science and Nutrition Division, National Research Centre, Dokki, 12311, Giza, Egypt

(Received June 13, 2005)

(Accepted June 18, 2005) 
Arab Univ. J. Agric. Sci., Ain Shams Univ., Cairo, 13(3), 669 - 676, 2005

دمجأيسلاون د.أ ل لبربنسوي دمحأ ن.جئكحت

1- Department of Biological Sciences, Faculty of Science, King Abdulaziz University, P.O. Box 80203, Jeddah 21589, Saudi Arabia

2- Department of Dairy Science, Food Science and Nutrition Division, National Research Centre, Dokki, 12311, Giza, Egypt

(Received June 13, 2005)

(Accepted June 18, 2005) 